\title{
АНАЛИЗ ТЕМПЕРАТУРЫ ГОРНЫХ ПОЧВ С ПРИМЕНЕНИЕМ МЕТОДОВ ОПИСАТЕЛЬНОЙ СТАТИСТИКИ
}

\author{
Штабровская И.М., Зенкова И.В. \\ Институт проблем промышленной экологии Севера КНЦ РАН, Апатиты, \\ ishtabrovskaya@mail.ru; zenkova@inep.ksc.ru
}

\begin{abstract}
Аннотация
В последние годы проводятся исследования температурного режима горных почв Мурманской области с использованием автономных программируемых терморегистраторов нового поколения [1-3]. Благодаря автономным терморегистаторам, мы получаем огромный массив первичных данных по температуре и влажности горных почв Хибинского горного массива, которые необходимо обрабатывать и анализировать. Получив первичный массив данных, его невозможно обработать без специальных компьютерных программ. Нами использован пакет анализа данных и его основные возможности: описательная статистика, дисперсионный анализ и корреляционный анализ.
\end{abstract}

\section{Summary}

In recent years, the researches the temperature regime of mountain soils in the Murmansk region has been studied using autonomous programmable thermoregulators of a new generation [1-3]. We get a huge array of primary data on the temperature and humidity of mountain soils of the Khibiny Mountain Massif, which must be processed and analyzed. Having received the primary data array, it can't be processed without special computer programs. We used a package of data analysis and its main features: descriptive statistics, variance analysis and correlation analysis.

\section{Объекты и методы}

Актуальность исследования температурного режима горных почв определяется несколькими аспектами:

- специфическими особенностями горного микроклимата, который отличается от климата предгорных ландшафтов и определяет особенности развития и функционирования горных почв и своеобразие их растительных, животных и микробных сообществ, а также оказывает влияние на климат окружающих предгорных ландшафтов.

- $\quad$ гетерогенностью почвенного покрова в горах, связанной с высотной поясностью экологических факторов и различной экспозицией горных экосистем;

- индикаторной ролью температурного режима уязвимых горных экосистем заполярных широт в комплексном мониторинге глобальных климатических процессов;

- появлением нового инструмента для учёта температурных показателей в виде автономных программируемых датчиков разной модификации.

Для целей исследования были выбраны 5 участков в горно-тундровом и горнолесном поясах с разной экспозицией в пределах горы Вудъяврчорр, расположенной в южной части Хибин (рис. 1). 


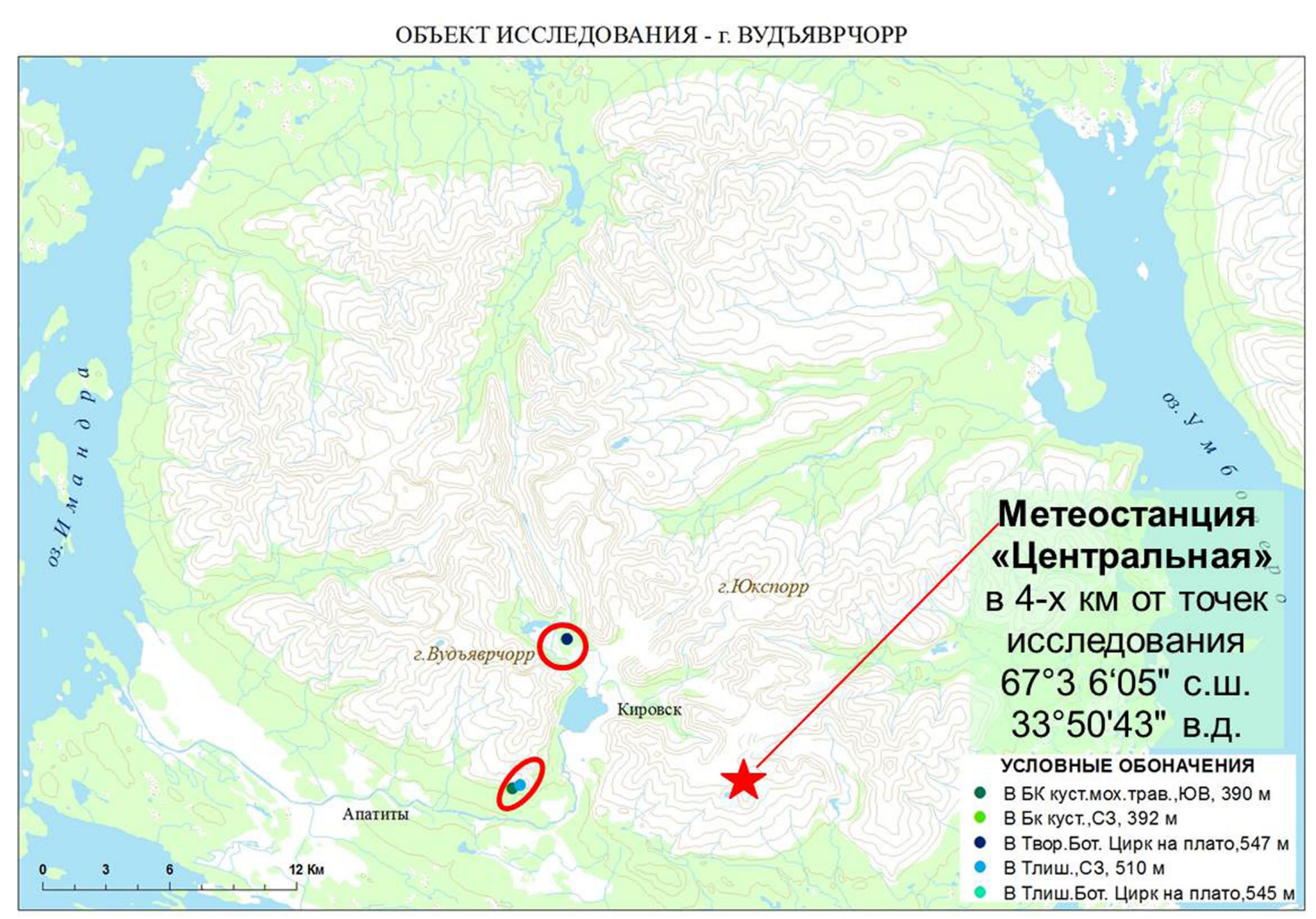

Рис. 1. Местоположение исследованных участков на территории Хибинского горного массива.

В поясе горной тундры два участка - тундра лишайниковая $\left(T_{\text {лиш}}\right)$ и тундра вороничная $\left(T_{B O P}\right)$ выбраны на плато Ботанического цирка, третий участок - тундра лишайниковая $\left(T_{\text {лиш-сз }}\right)$ - на склоне северо-западной экспозиции ущелья Скальное. Оба участка горнолесного пояса были выбраны на сходной высоте на склонах встречной экспозиции ущелья Скальное: участок берёзового криволесья кустарничково-травяно-мохового $\left(Б K_{ю в}\right)-$ на слоне ЮВ экспозиции, участок берёзового криволесья кустарничкового $\left(5 K_{C 3}\right)-$ на слоне СЗ экспозиции (рис. 2). Работы были выполнены в полевой сезон 2016 г. в Ботаническом цирке и в сезон 2017 года в ущелье Скальное. Характеристика участков приведена в табл. 1.

В полевые сезоны 2016 и 2017 г. в подстилку всех участков на глубину 5 см были заложены автоматические терморегистраторы (термохроны) (рис. 3), запрограммированные на измерение температуры в подстилках каждые 2 часа (внутрисуточная динамика) в период с конца июня до начала октября (летняя динамика).

Сроки закладки и выемки термодатчиков были приурочены к периодам схода снега и начала заморозков в Хибинском горном массиве. Использовали датчики серии ТРВ-2 с техническими характеристиками, наиболее подходящими для климатических условий Мурманской области, в частности, с предельным диапазоном измерений температуры от $-25^{\circ} \mathrm{C}$ до $+40^{\circ} \mathrm{C}$. После выемки термохронов из почвы данные переносили на компьютер при помо- 
Ботанический цฺирк, 2016 г. Горно-тундровый пояс.

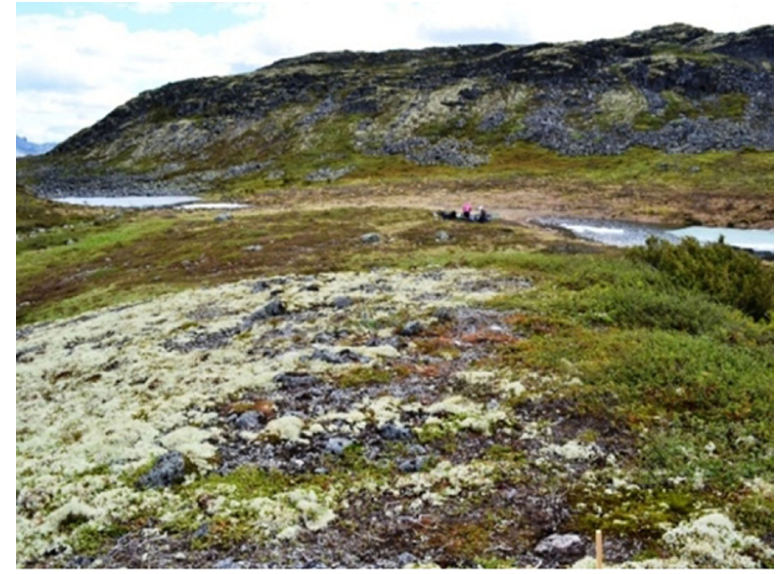

Тундра лишайниковая $\left(T_{\text {лиш}}\right)$.

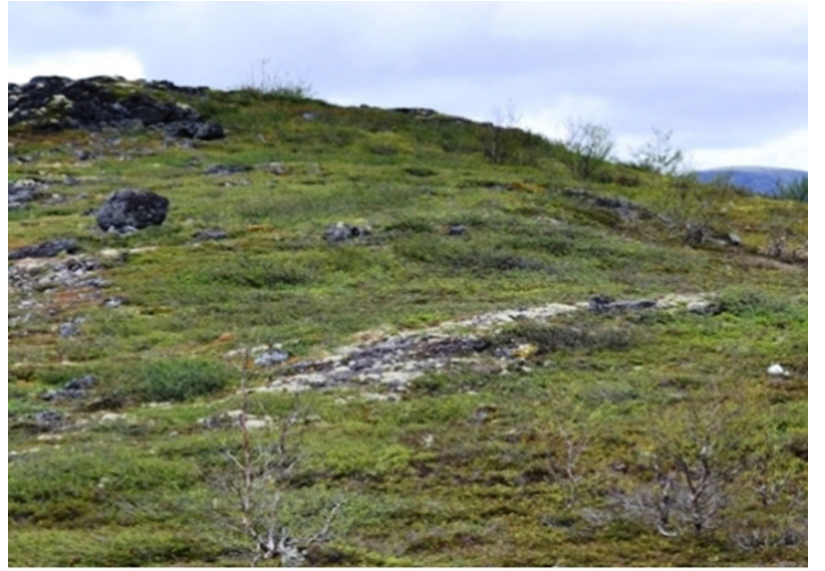

Тундра вороничная $\left(T_{\text {воР }}\right)$.

Ущзелье скальное, 2017 г. Горно-тундровый пояс.

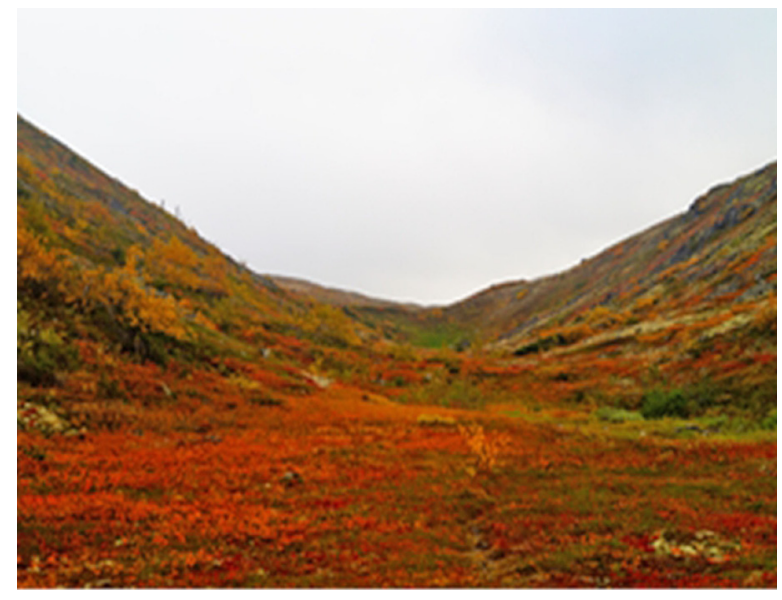

Тундровый пояс ущзелья.

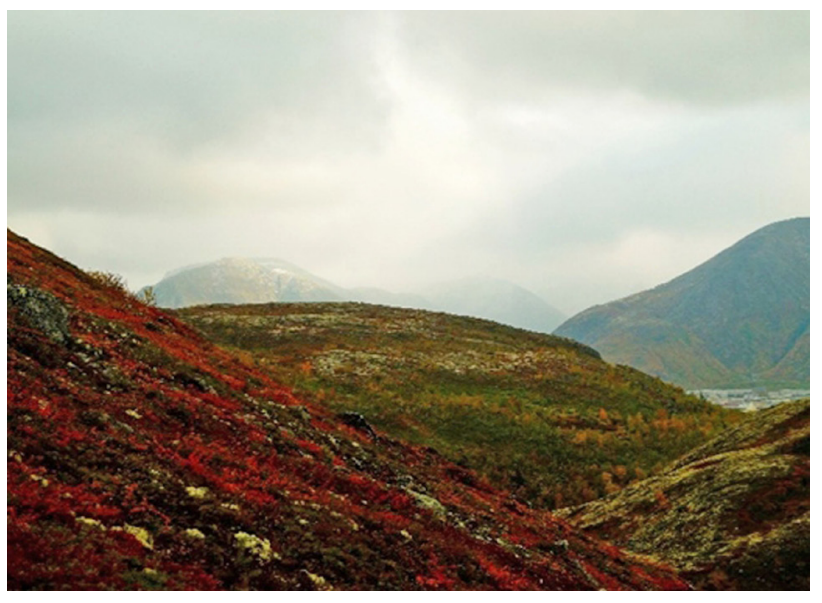

Тундра лишайниковая, С3 $\left(T_{\text {лиш-сз }}\right)$.

Горно-лесной пояс.

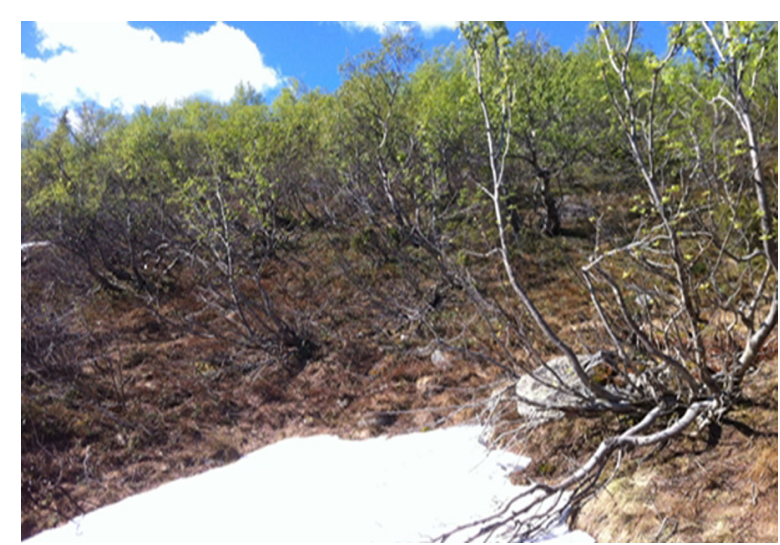

Березовое криволесье кустарничковотравяно-моховое $\left(Б К_{ю в}\right)$.

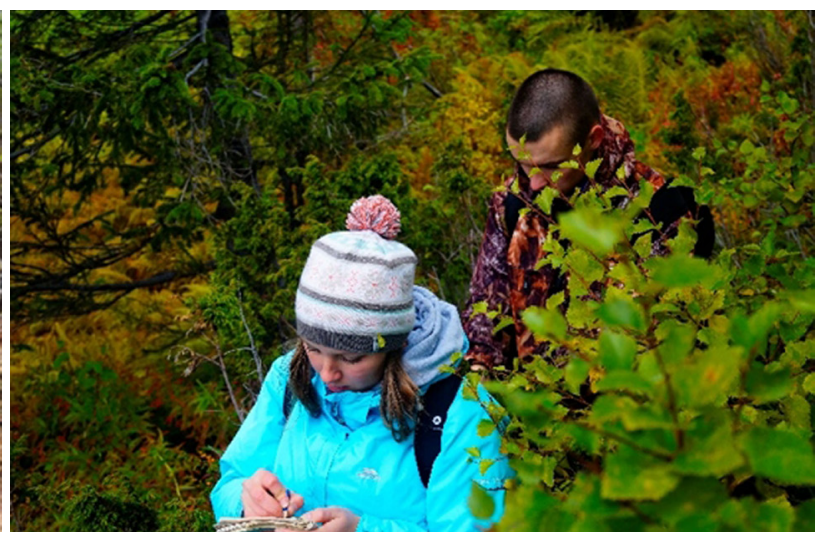

Березовое криволесье кустарничковое $\left(\right.$ БК $\left.{ }_{C 3}\right)$.

Рис. 2. Участки горной тундры и березового криволесья, обследованные на плато и склонах горы Вудъяврчорр.

щи специального USB-переходника и управляющей программы (рис. 4). Полученные данные обрабатывались в программах Excel и Statistica-10 (описательная статистика, корреляционный и дисперсионный анализ). 

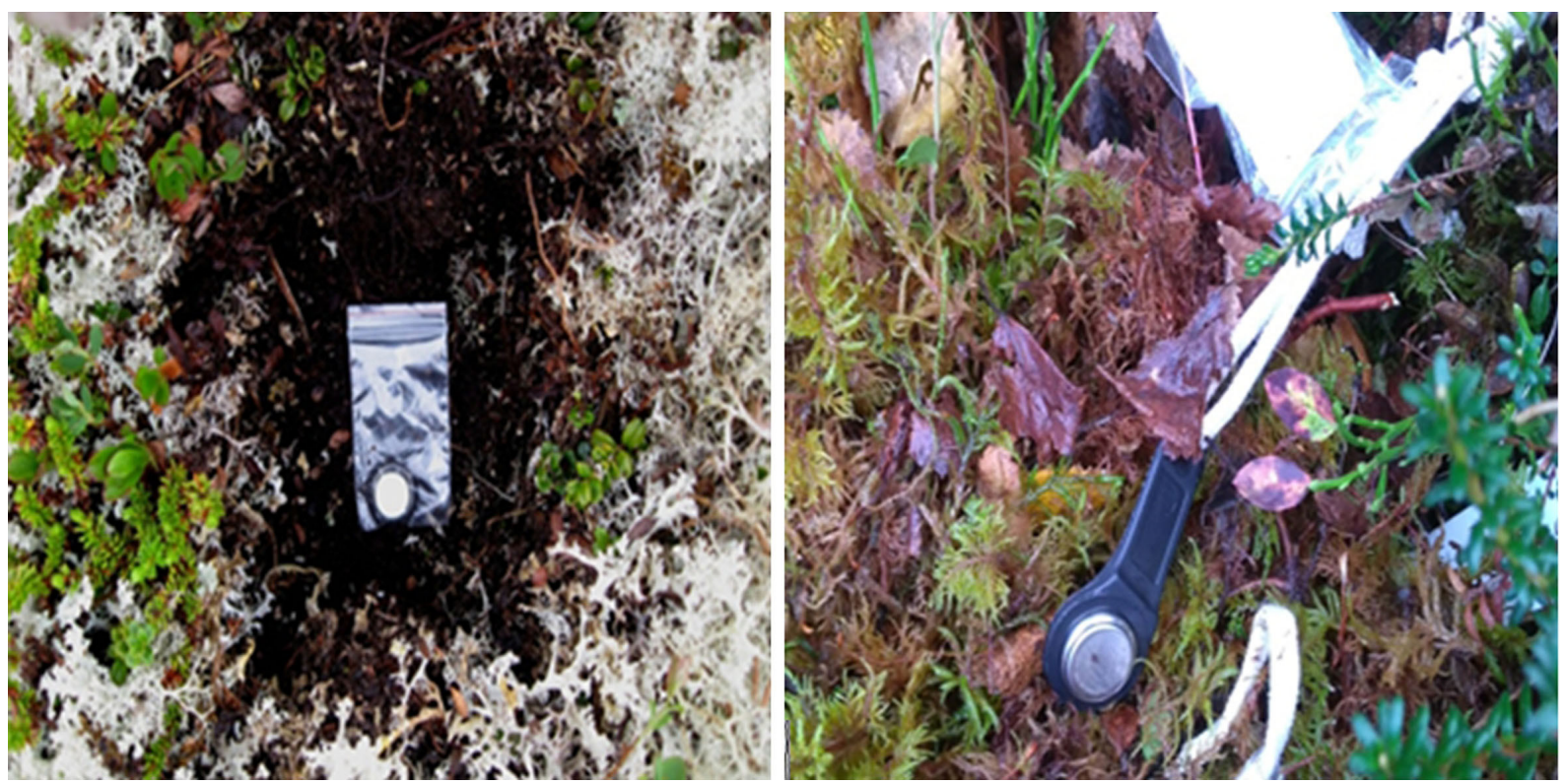

Рис. 3. Закладка автоматических датчиков температуры (термохронов) в подстилку на глубину 5 см.

По 12 измерениям за каждые сутки рассчитывали среднесуточные значения температуры подстилок $\left(T c y m_{c p}\right)$. По усреднённым среднесуточным значениям вычисляли среднемесячные температуры подстилок для каждого месяца (Tмес $\left.{ }_{c p}\right)$, по значениям, усреднённым за весь период исследования, среднелетние значения (Тлет $\left.{ }_{c p}\right)$.

Сравнивали максимальные и минимальные внутрисуточные, среднесуточные и среднелетние температуры, а также суммы эффективных температур между соседними поясами в пределах одного склона - склона С3 экспозиции (БК $K_{C 3}$ и $T_{\text {лиш-сз }}$ ) и между участками одного (тундрового) пояса в разные сезоны с использованием t-критерия Стьюдента. При сравнении динамики температуры между участками, исследованными в каждый из сезонов,
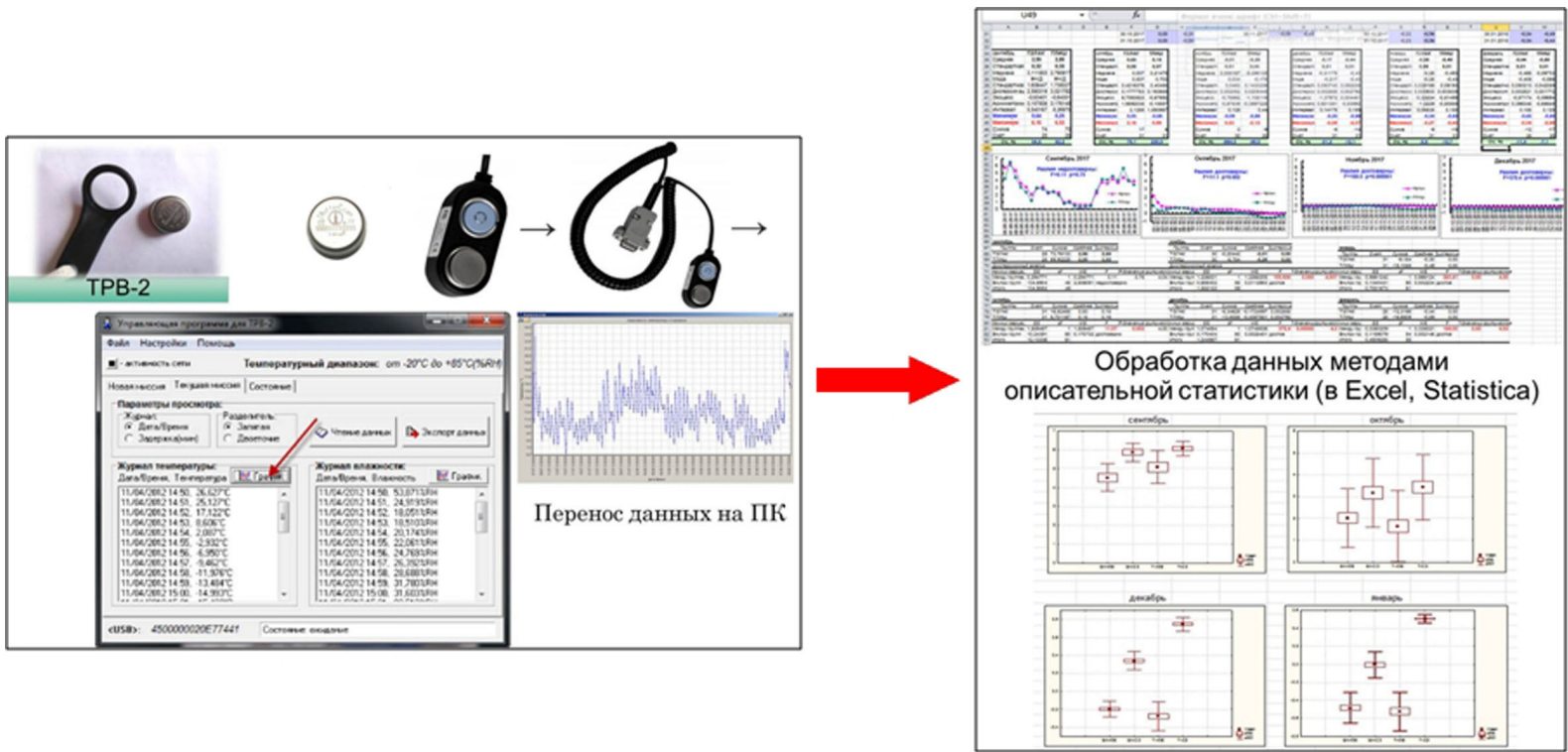

Рис. 4. Схема переноса информации с термохрона на компьютер и обработка при помощи программных пакетов Excel и Statistica-10. 
учитывали сходный период измерений: в 2016 г. с 22.06.2016 по 05.10.2016 (106 сут); в 2017 г. - с 03.07.17 по 20.09.17 (80 сут). Сравнение общей динамики и показателей температуры для 5 участков за два вегетационных сезона проводили для двух наиболее тёплых месяцев - июля и августа, т.е. за период 60 суток.

Методом корреляционного анализа оценивали зависимость летней динамики среднесуточной температуры подстилок и атмосферного воздуха за аналогичный период исследования. Динамику температуры атмосферного воздуха за период исследования анализировали по данным метеостанции «Центральная» [7] в 4-х км от исследованных участков (рис. 1). Для оценки достоверности коэффициентов корреляции при корреляционном анализе с метеоданными использовали t-критерий Стьюдента.

Таблица 1. Характеристика участков Ботанического цирка

и ущелья Скальное.

\begin{tabular}{|c|c|c|c|c|c|c|}
\hline \multirow[b]{2}{*}{ Участок } & \multicolumn{2}{|c|}{$\begin{array}{c}\text { Ботанический } \\
\text { цирк, } 2016 \text { г. }\end{array}$} & \multicolumn{3}{|c|}{ Ущелье Скальное, 2017 г. } & \multirow[t]{2}{*}{ Всего } \\
\hline & 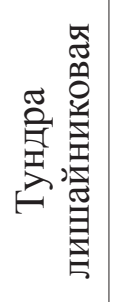 & 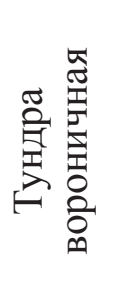 & 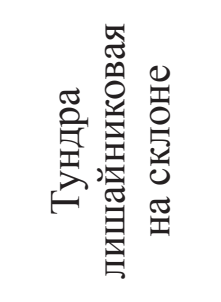 & 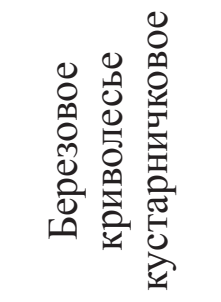 & 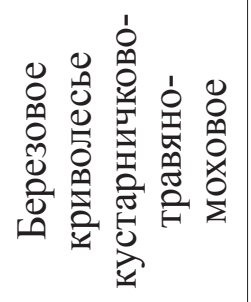 & \\
\hline $\begin{array}{l}\text { Экспозиция } \\
\text { склона }\end{array}$ & \multicolumn{2}{|c|}{ плато } & C3 & C3 & ЮВ & 2 \\
\hline Аббревиатура & $T_{\text {лиш }}$ & $T_{B O P}$ & $T_{\text {лиш-сз }}$ & $5 K_{C 3}$ & $Б K_{Ю B}$ & 5 \\
\hline $\begin{array}{l}\text { Горно- } \\
\text { растительный } \\
\text { пояс }\end{array}$ & \multicolumn{2}{|c|}{$\begin{array}{l}\text { Горно- } \\
\text { тундровый }\end{array}$} & $\begin{array}{c}\text { Горно- } \\
\text { тундровый }\end{array}$ & \multicolumn{2}{|c|}{$\begin{array}{c}\text { Пояс берёзовых криво- } \\
\text { лесий }\end{array}$} & 2 \\
\hline $\begin{array}{l}\text { Высота над } \\
\text { ур. м., м }\end{array}$ & 545 & 547 & 510 & \multirow{2}{*}{$\begin{array}{c}392 \\
67^{\circ} 35^{\prime} 56,8^{\prime \prime} \\
33^{\circ} 35^{\prime} 44,3^{\prime \prime}\end{array}$} & 390 & \\
\hline Координаты & $\begin{array}{l}67^{\circ} 38 \\
33^{\circ} 3\end{array}$ & $\begin{array}{l}\text { 4" с. ш. } \\
\text { 2" в. д. }\end{array}$ & $\begin{array}{l}67^{\circ} 36^{\prime} 01,8^{\prime \prime} \\
33^{\circ} 36^{\prime} 16,6^{\prime \prime}\end{array}$ & & $\begin{array}{l}67^{\circ} 35^{\prime} 56,9^{\prime \prime} \\
33^{\circ} 35^{\prime} 42,4^{\prime \prime}\end{array}$ & \\
\hline
\end{tabular}

Вариабельность ежемесячной (за июль, август, сентябрь) и летней (с июля по сентябрь) динамики температуры подстилок оценивали по коэффициенту вариации $C V, \%$.

Достоверность различий температурной динамики подстилок между участками разных высотных поясов и разной экспозиции оценивали методом дисперсионного анализа с использованием F-критерия Фишера. Все оцениваемые параметры сведены в табл. 2. 
Таблица 2. Температурные показатели, рассчитанные на основе данных термохронов.

\begin{tabular}{|c|c|c|c|}
\hline \multirow[b]{2}{*}{ Показатели } & \multicolumn{3}{|c|}{ Динамика температуры подстилок } \\
\hline & $\begin{array}{c}\text { Суточная, } \\
12 \text { показаний } \\
\text { с интервалом } 2 \text { часа }\end{array}$ & $\begin{array}{l}\text { Месячная, } \\
\text { за VII, VIII, IX }\end{array}$ & $\begin{array}{c}\text { Летняя, } \\
\text { за сезон VII - IX }\end{array}$ \\
\hline $\begin{array}{c}\text { Минимальные } \\
\text { температуры, }{ }^{\circ} \mathrm{C}\end{array}$ & $T_{C y T \min }$ & $T_{M E C \min }$ & $T_{\text {ЛETmin }}$ \\
\hline $\begin{array}{c}\text { Максимальные } \\
\text { температуры, }{ }^{\circ} \mathrm{C}\end{array}$ & $T_{C y T \max }$ & $T_{M E C \max }$ & $T_{\text {ЛET } \max }$ \\
\hline $\begin{array}{c}\text { Колебания } \\
\text { температуры, }{ }^{\circ} \mathrm{C}\end{array}$ & $T_{C Y T \max }-T_{C y T \min }$ & $T_{M E C \max }-T_{M E C \min }$ & 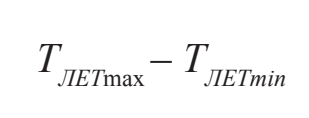 \\
\hline $\begin{array}{c}\text { Вариабельность } \\
\text { температуры } \\
\text { (коэфф. вариации, \%) }\end{array}$ & $C V_{C У T}$ & $C V_{M E C}$ & $C V_{\text {ЛЕT }}$ \\
\hline $\begin{array}{l}\text { Среднее значение } \\
\text { температуры, }{ }^{\circ} \mathrm{C}\end{array}$ & $\begin{array}{c}\text { Среднесуточная } \\
\text { температура } \\
T_{\text {Сутср }}\end{array}$ & $\begin{array}{c}\text { Среднемесячная } \\
\text { температура } \\
T_{M E C \text { ср }}\end{array}$ & $\begin{array}{c}\text { Среднелетняя } \\
\text { температура } \\
T_{Л Е T \mathrm{p}}\end{array}$ \\
\hline $\begin{array}{c}\text { Сумма положительных } \\
\text { температур, }{ }^{\circ} \mathrm{C}\end{array}$ & не рассм. & $\begin{array}{c}\sum T_{M E C \mathrm{cp}}>0 \\
\sum T_{M E C \mathrm{cp}} \geq+5 \\
\sum T_{M E C \mathrm{cp}} \geq+10\end{array}$ & 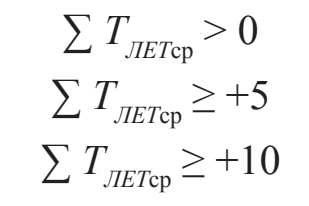 \\
\hline
\end{tabular}

Для визуализации данных по средним значениям температуры горных подстилок в разных высотных поясах и на разных горах Хибинского массива выполняли построение карт в программном пакете ArcGIS (версия 10.4) компании ESRI.

\section{Результаты}

Результаты исследования температурного режима, полученные в 2016 и 2017 годах [6, 7], сравнивали с данными собственных исследований в 2014 и 2015 годах, выполненных на склонах Хибинских гор Юкспорр и Суолайв в рамках подготовки бакалаврской квалификационной работы [4]. Также были использованы данные по температуре подстилок на склонах гор Рисчорр, Партомчорр и в межгорной (Путеличорр/Парттомчорр) долине реки Кунийок, полученные в.н.с. Лаборатории наземных экосистем ИППЭС ФИЦ КНЦ РАН И. В. Зенковой в 2013 и 2015 гг. [2, 3, 5] (табл. 3). Общее число участков, на которых были выполнены исследования температуры, составило 11.

Для 5 участков, исследованных в горно-лесном и горно-тундровом поясах горы Вудъяврчорр в полевые сезоны 2016 и 2017 гг., проведено сравнение температурных показателей и их динамики за два наиболее тёплых летних месяца - июль и август (60 суток). Диапазон среднесуточных значений темпера-

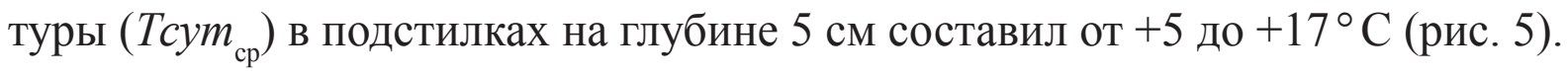


Таблица 3. Местоположение участков в Хибинском горном массиве, на которых выполнены измерения температуры подстилок в 2013-2017 гг.

\begin{tabular}{|c|c|c|c|c|}
\hline Гора & $\begin{array}{c}\text { Экспозиция } \\
\text { склона }\end{array}$ & $\begin{array}{c}\text { Горно- } \\
\text { растительный пояс }\end{array}$ & Координаты & $\begin{array}{c}\text { Высота } \\
\text { над ур. } \\
\text { м., м }\end{array}$ \\
\hline Партомчорр & ЮB & Северо-таежный & $\begin{array}{l}67^{\circ} 49^{\prime} 39^{\prime \prime} \text { с. ш., } \\
33^{\circ} 40^{\prime} 18^{\prime \prime} \text { в. д. }\end{array}$ & $290-310$ \\
\hline \multirow{3}{*}{ Рисчорр } & $\mathrm{C}$ & Горно-тундровый & $67^{\circ} 49^{\prime} 17^{\prime \prime}, 33^{\circ} 40^{\prime} 04^{\prime \prime}$ & 430 \\
\hline & C3 & Лесотундровый & $67^{\circ} 49^{\prime} 22^{\prime \prime}, 33^{\circ} 40^{\prime} 10^{\prime \prime}$ & $360-380$ \\
\hline & C3 & Северо-таежный & $67^{\circ} 49^{\prime} 36^{\prime \prime}, 33^{\circ} 40^{\prime} 06^{\prime \prime}$ & $290-310$ \\
\hline \multirow{2}{*}{$\begin{array}{l}\text { Долина реки } \\
\text { Кунийок } \\
\text { (между горами } \\
\text { Путеличорр и } \\
\text { Партомчорр) }\end{array}$} & \multirow[b]{2}{*}{$\begin{array}{c}\text { межгорная } \\
\text { долина }\end{array}$} & Горно-лесной & $67^{\circ} 50^{\prime} 14.8^{\prime \prime}, 33^{\circ} 39^{\prime} 37.3^{\prime \prime}$ & 235 \\
\hline & & Горно-лесной(ГЛ) & $67^{\circ} 50^{\prime} 16.4^{\prime \prime}, 33^{\circ} 39^{\prime} 22.5^{\prime \prime}$ & 236 \\
\hline \multirow{3}{*}{ Юкспорр } & плато & Горно-тундровый & $67^{\circ} 39^{\prime} 32^{\prime \prime}, 33^{\circ} 46^{\prime} 44^{\prime \prime}$ & $710-730$ \\
\hline & ЮB & Горно-тундровый & $67^{\circ} 39^{\prime} 06^{\prime \prime}, 33^{\circ} 46^{\prime} 44^{\prime \prime}$ & $625-645$ \\
\hline & ЮB & Лесотундровый & $67^{\circ} 38^{\prime} 59^{\prime \prime}, 33^{\circ} 47^{\prime} 17^{\prime \prime}$ & $460-490$ \\
\hline \multirow{3}{*}{ Суолайв } & 3 & Горно-тундровый & $67^{\circ} 39^{\prime} 32^{\prime \prime}, 34^{\circ} 10^{\prime} 03^{\prime \prime}$ & $387-550$ \\
\hline & 3 & Лесотундровый & $67^{\circ} 39^{\prime} 30^{\prime \prime}, 34^{\circ} 10^{\prime} 13^{\prime \prime}$ & $328-340$ \\
\hline & 3 & Горно-лесной & $67^{\circ} 39^{\prime} 26^{\prime \prime}, 34^{\circ} 10^{\prime} 14^{\prime \prime}$ & $260-270$ \\
\hline
\end{tabular}

Наибольшим прогревом на протяжении июля и до 10 августа характеризовалась подстилка $T_{\text {лиш }}$ на площадке Ботанического цирка, наименьшим - $T_{\text {лиш-сз. }}$ В этот период различия в температурной динамике между двумя горно-тундровыми участками определялись в первую очередь их положением на разных площадках (Ботанический цирк и ущелье Скальное), которые были исследованы в разные полевые сезоны (2016 и 2017 гг.), достоверно различающиеся по температурным условиям сезоны (рис. 6).

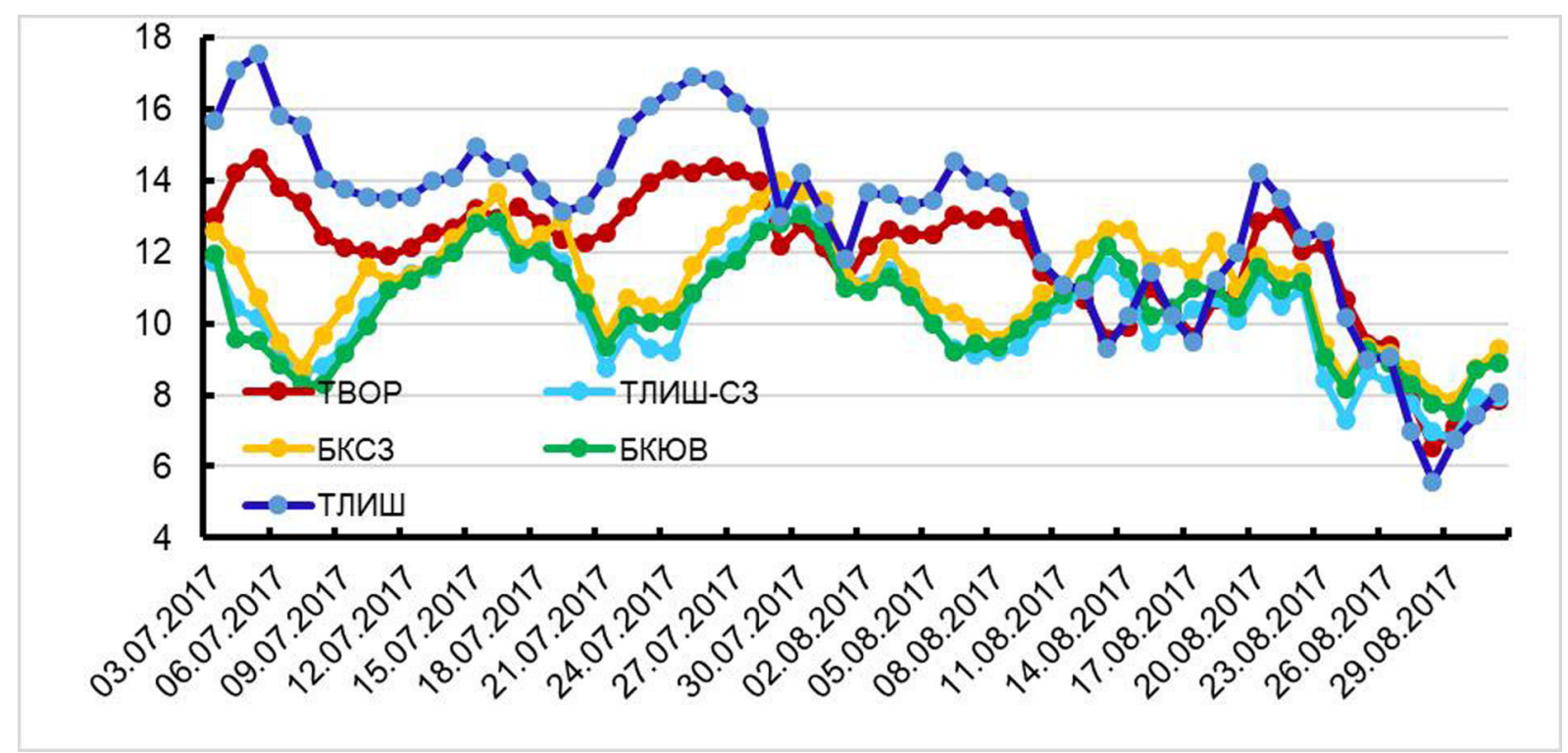

Рис. 5. Динамика среднесуточной температуры подстилок $\left(\right.$ Tсут $\left._{c p^{\prime}}{ }^{\circ} \mathrm{C}\right)$ за июльавгуст на исследованных участках горно-лесного и горно-тундрового поясов на площадке Ботанического ијирка и в ущелье Скальное (60 сут, сезоны 2016, 2017 гг.). 


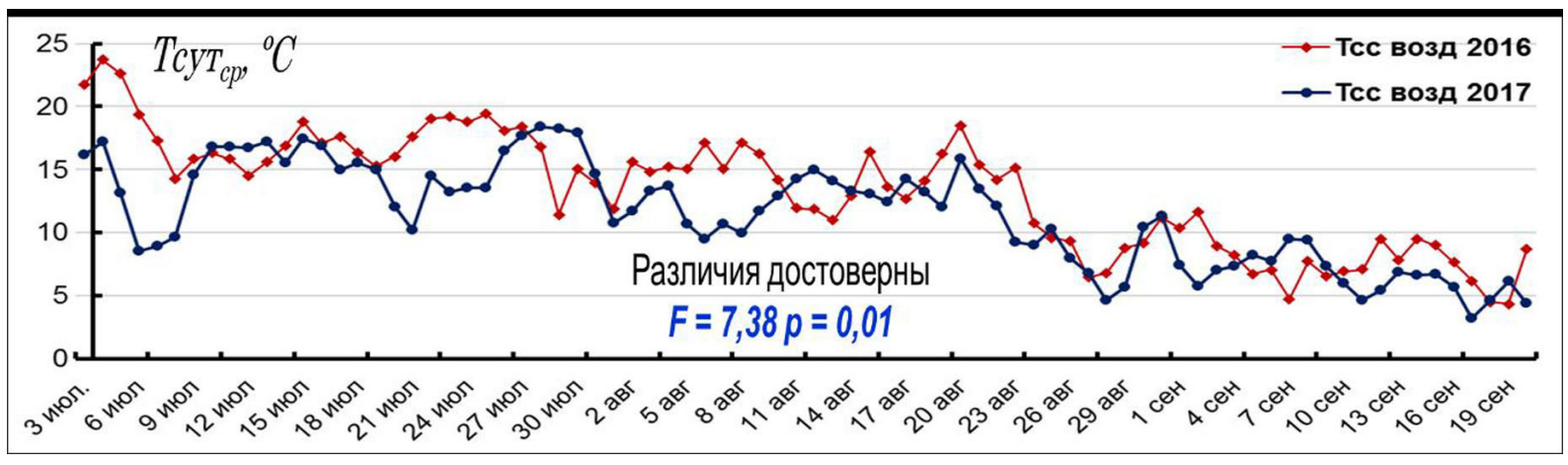

Рис. 6. Достоверное различие величины и динамики среднесуточной температуры атмосферного воздуха на протяжении вегетационных сезонов 2016 и 2017 г2.

Однако, начиная с 20-ых чисел августа, в подстилках всех участков наблюдалась сходная динамика $T c y m_{\text {ср }}$, связанная с уменьшением межсезонных различий в динамике $T c y m_{\text {ср }}$ атмосферного воздуха (см. рис. 5, 6). В частности, устойчивое осеннее снижение $T c y m_{c p}<+10^{\circ} \mathrm{C}$ в тундровых подстилках на площадке Ботанического цирка в сезон 2016 г. отмечено с 25 августа и на всех участках в ущелье Скальное в сезон 2017 г. - с 23 августа.

Следовательно, к концу вегетационного сезона, когда температура воздуха имеет сходные или более низкие значения по сравнению с температурой подстилок, различия в температурной динамике, определяемые положением участков в пределах горы Вудъяврчорр, а также межгодовыми различиями в прогреве атмосферного воздуха, становятся невыраженными.

Достоверная корреляция летней динамики температуры в горных подстилках с ходом Tcym ср температуры атмосферного воздуха в сезоны 2016 и 2017 гг. установлена для всех исследованных участков (рис. 7). Коэффициент корреляции превысил уровень 0.9 и был выше для более сухой и тонкой подстилки тундры лишайниковой в Ботаническом цирке (0.96).

Средние за два месяца значения температура (Тлет ср) варьировали от $+10.3 \pm 0.2{ }^{\circ} \mathrm{C}$ в $T_{\text {лиш-сз }}$ на склоне С3 экспозиции ущелья Скальное до $12.9 \pm 0.4{ }^{\circ} \mathrm{C}$ в $T_{\text {лиш }}$ на площадке Ботанического цирка, при этом как наименьшие, так и наибольшие значения Tлет ср были характерны для подстилок горно-тундрового пояса (рис. 8).
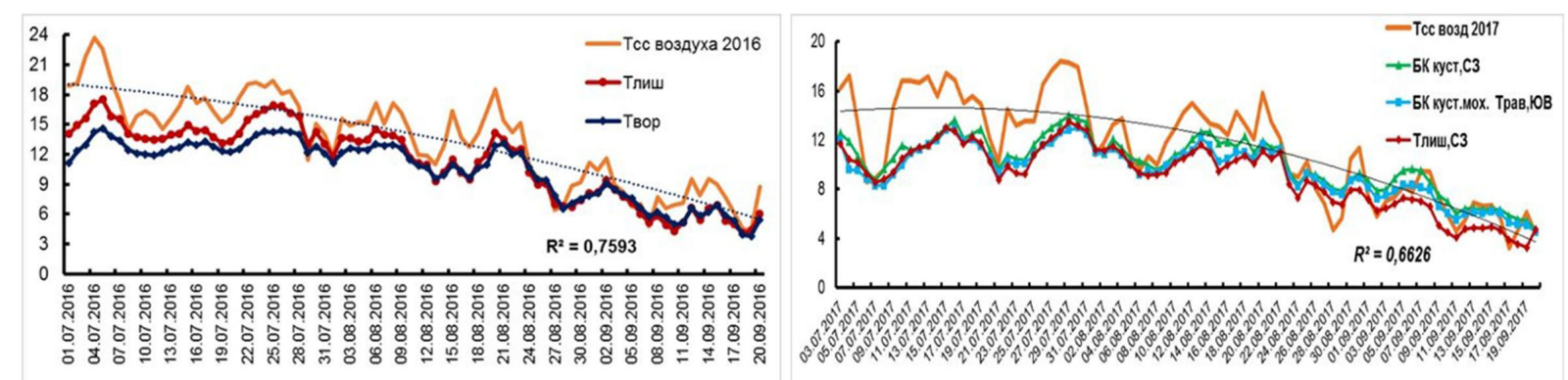

Рис. 7. Корреляция динамики среднесуточной температуры подстилки $\left({ }^{\circ}\right.$ C) на участках горно-лесного и горно-тундрового поясов г. Вудъяврчорр с температурой атмосферного воздуха в сезоны 2016 и 2017 г2. 


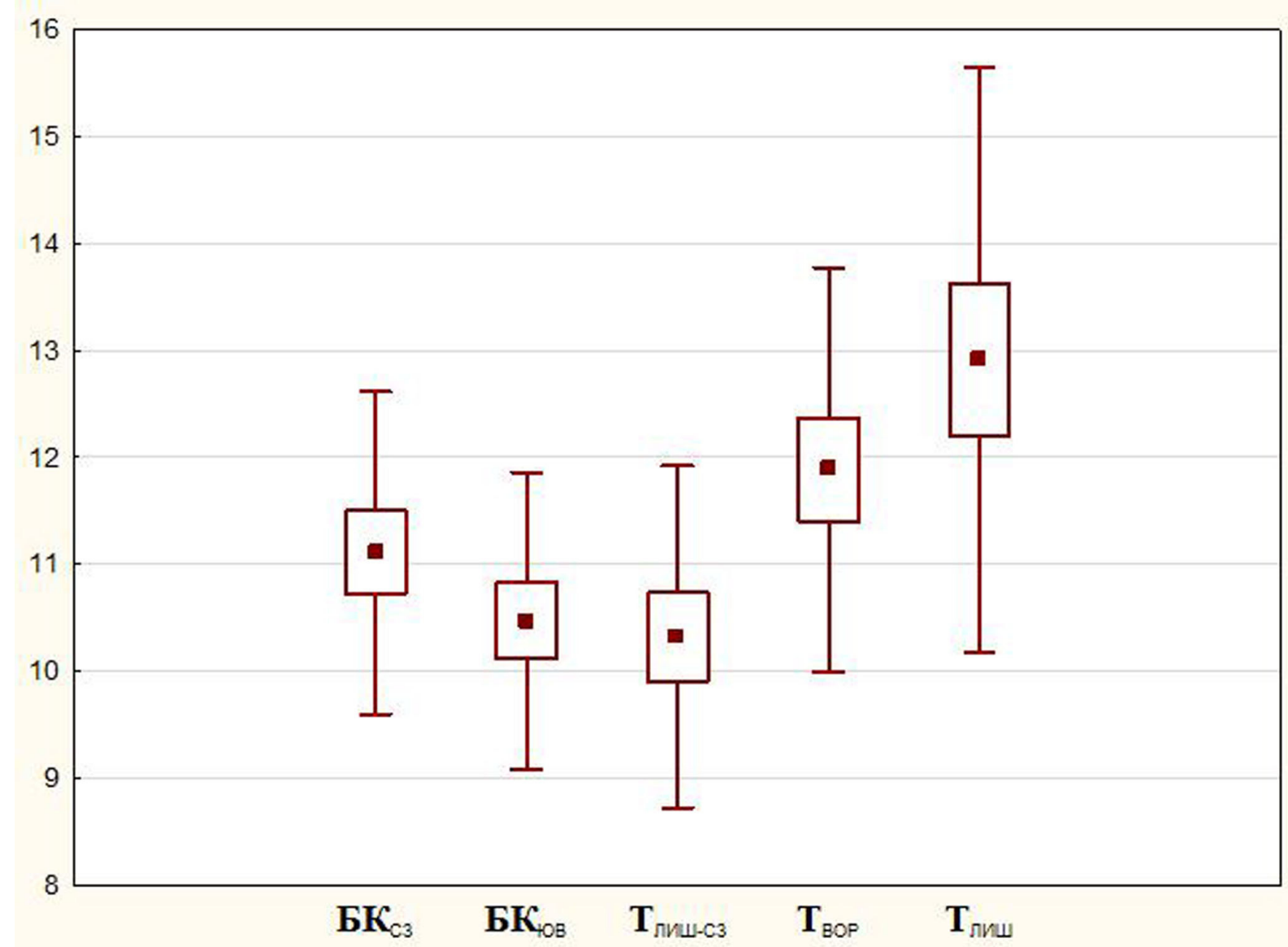

Рис. 8. Средние значения температуры подстилки на участках березового криволесья и горной тундры в ущзелье Скальное и на площуакке Ботанического циирка за июль-август 2016 и 2017 г.г. (Тлет ${ }_{c p},{ }^{\circ} \mathrm{C} ; 60$ cym).

Сравниваемые значения достоверно отличались между всеми участками, но в большей степени - между более сухой и тонкой подстилкой $T_{\text {лиш }}$ и более холодной и влажной $Б K_{ю в}$, а в меньшей степени - между $T_{\text {лиш }} / T_{B O P}$ и $T_{\text {воР }} /$ БК

Таблица 4. Значения t-критерия Стьюдента при сравнении средних за июль-август значений температуры подстилок между пятью исследованными участками.

\begin{tabular}{|c|c|c|c|c|c|c|c|c|}
\hline & $T_{\text {ЛИШ }} / T_{\text {ВОР }}$ & $T_{\text {лиш_сз }} T_{\text {лиш }}$ & $T_{\text {ЛИшСз }} / T_{\text {вОР }}$ & $T_{\text {лиш }} / Б K_{\text {Сз }}$ & $T_{\text {Лиш }} / Б K_{\text {юв }}$ & $T_{B O P} / 5 K_{C 3}$ & $T_{B O P} / Б K_{\digamma O B}$ & $Б K_{C \zeta} / Б K_{\digamma O b}$ \\
\hline$t_{\text {st }}$ & 2.39 & 6.33 & 4.90 & 4.47 & 6.15 & 2.49 & 4.69 & 2.41 \\
\hline
\end{tabular}

Различие достоверно при $\mathrm{t}_{(118 ; 0.01)} \geq 2.61$.

Общей особенностью динамики температуры подстилок в самые тёплые летние месяцы была её большая вариабельность в подстилках горнотундровых поясов (как на площадке Ботанического цирка в 2016 г., так и на склоне С3 экспозиции в 2017 г.) по сравнению с участками на склонах разной экспозиции горно-лесного пояса (рис. 9). Это объясняется сглаживанием температурных колебаний в подстилках под пологие леса. 


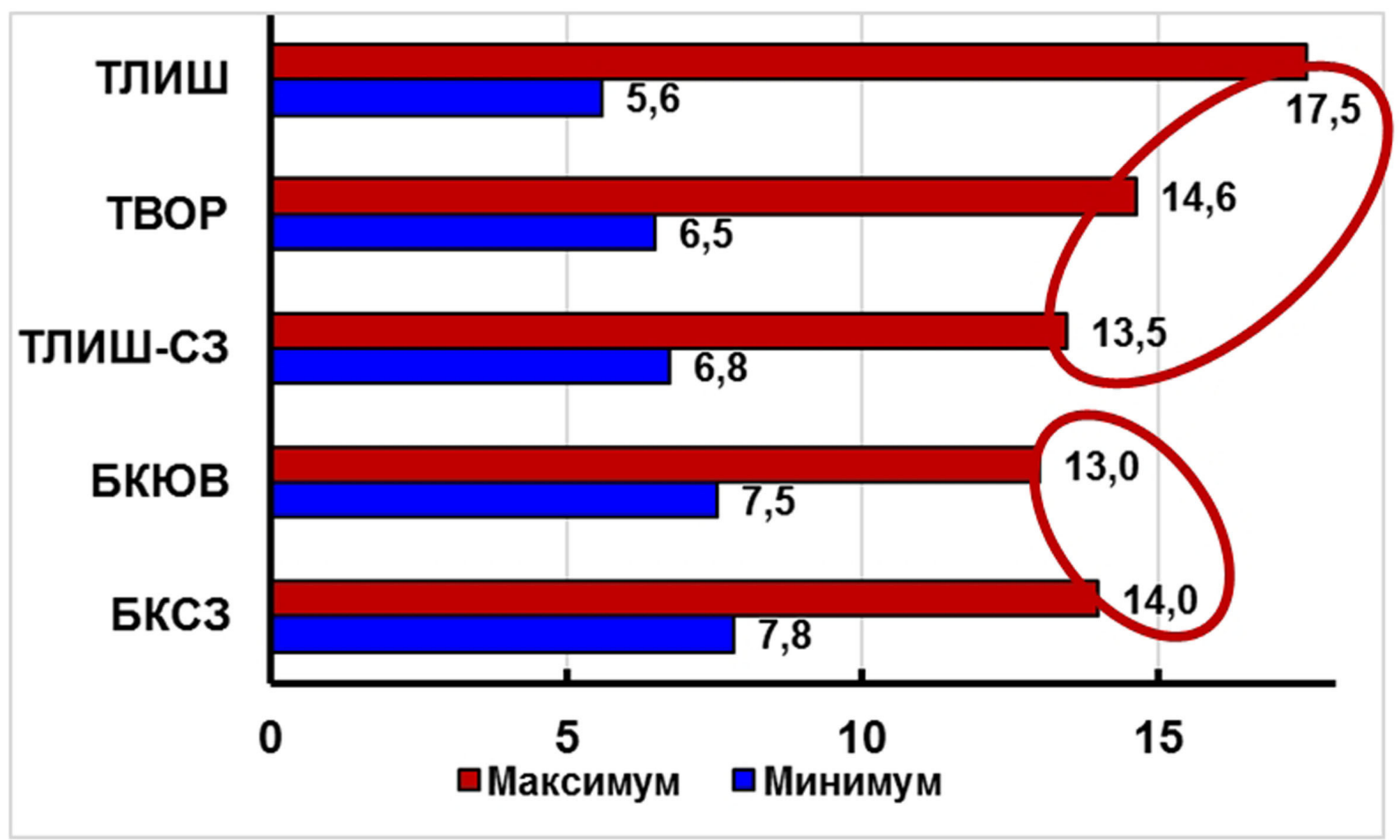

Рис. 9. Степень варьирования среднесуточной температуры подстилок на исследованных участках горно-тундрового и горно-лесного поясов за июль-август 2016 и 2017 г2. (значения коэффициента вариаџии CV, \%; $n$ сут=60).

Различия между участками горно-лесного пояса определялись преимущественно различиями в максимальных среднесуточных значениях температуры подстилок и, в меньшей степени, - различиями минимальных значе-

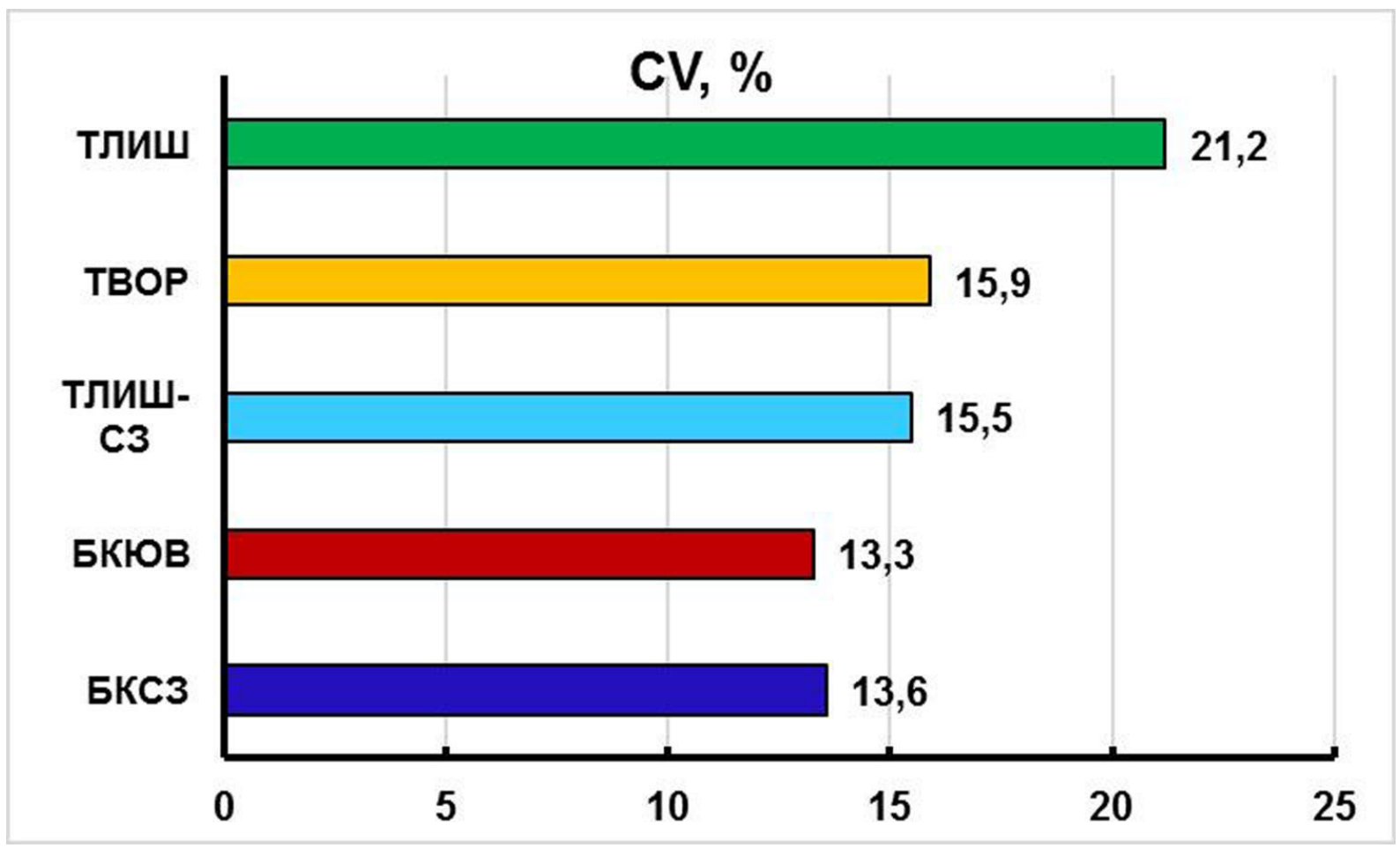

Рис. 10. Минимальные и максимальные значения среднесуточной температуры подстилок горно-тундрового и горно-лесных поясов на исследованных участках за июль-август 2016 и 2017 г.2. (60 cym). 


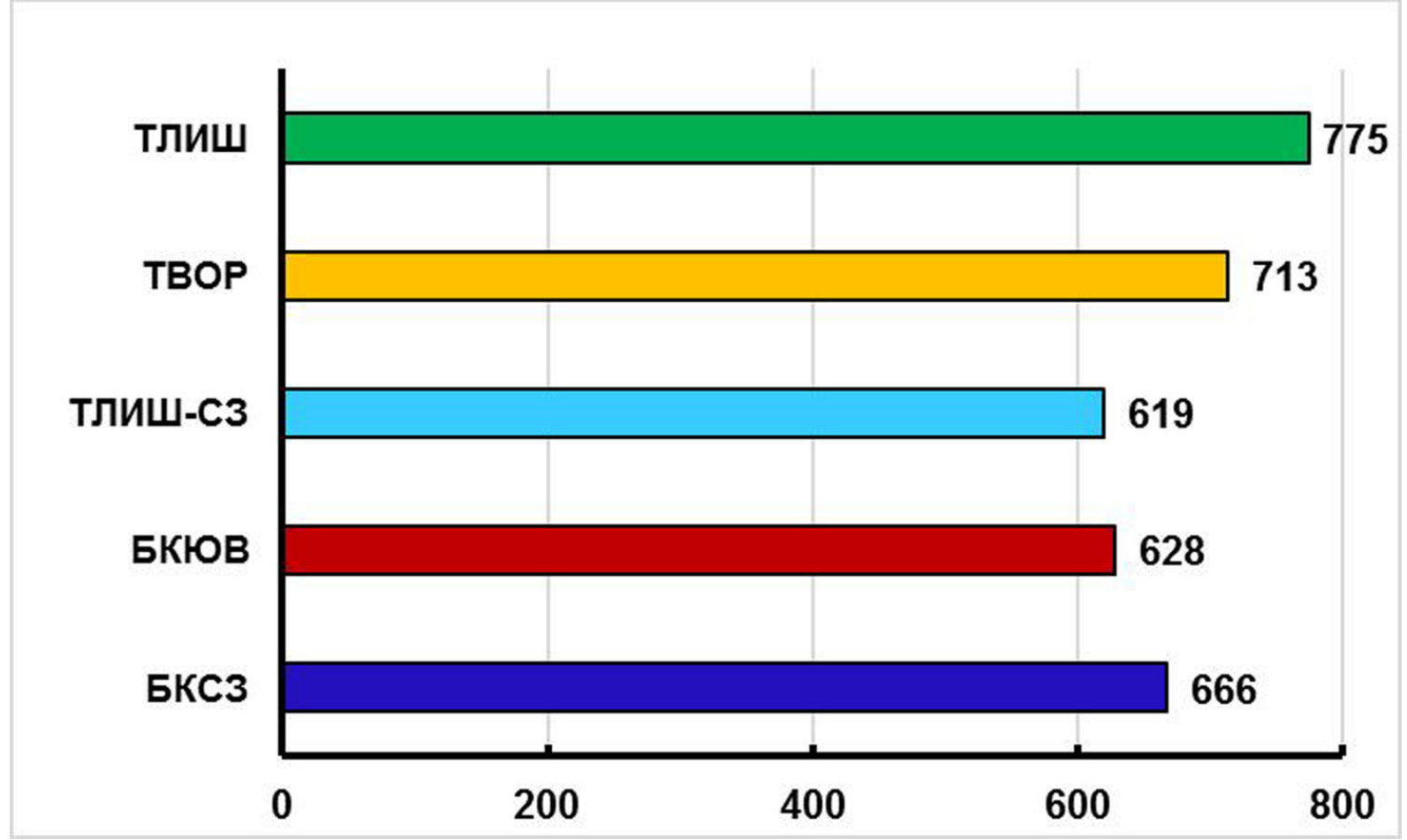

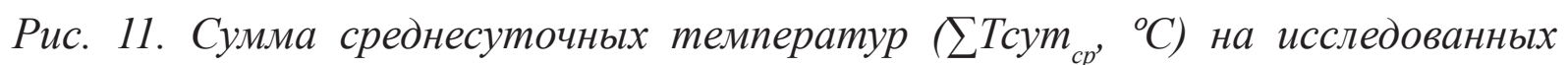
участках за июль-август (60 сут, сезонь 2016-2017 г2.).

ний. В горно-тундровых подстилках влияние на различие в вариабельности температурной динамики подстилок оказывала разница как в минимальных, так и в максимальных значениях температуры (рис. 10).

Сумма положительных температур $\sum T c y m_{\text {ср }}$ подстилок за два наиболее тёплых летних месяца составила $620-670^{\circ} \mathrm{C}$ в горных подстилках ущелья Скальное в более прохладное лето 2017 г. и превысила $700^{\circ} \mathrm{C}$ в горнотундровых подстилках Ботанического цирка в более тёплый сезон 2016 г. (рис. 11).

Обобщая полученные данные по температурным показателям и их летней динамике в экосистемах горы Вудъяврчорр, можно выделить три фактора, оказывающие дифференцирующее влияние на температурный режим горных подстилок: «сезонность», «экспозиция горного склона» и «высотная поясность». Фактор сезонности является основным и определяет сезонное изменение температуры атмосферного воздуха, которая влияет на процессы прогрева и охлаждения подстилок. Следовательно, он оказывает влияние на сезонную смену процесса поглощения и излучения тепла подстилками в осенний период. Высотная поясность определяет достоверные различия среднемесячных, минимальных и максимальных внутрисуточных и среднелетних значений температуры в подстилках; различия в динамике среднесуточных температур, в её сезонной вариабельности, в сроках перехода через среднесуточное значение температуры $<+5^{\circ} \mathrm{C}$ в конце вегетационного сезона (в сентябре). Эти различия проявляются для горно-лесного и горнотундрового поясов на протяжении всего вегетационного сезона, причем усиливаются от июля к сентябрю, то есть так же подвержены влиянию факто- 
ра сезонности. Экспозиция горных склонов определяет различия в таких показателях температурного режима горно-лесных подстилок, как: среднемесячные и максимальные значения температуры, число суток с эффективными $\operatorname{Tcym}_{\mathrm{cp}} \geq+10$ и $<+10^{\circ} \mathrm{C}$, сумма положительных температур в подстилке. Однако достоверное дифференцирующее влияние этого фактора установлено для горно-лесных подстилок только в самый тёплый месяц вегетационного сезона - июль.

\section{Заключение}

Благодаря регистраторам температуры нового поколения - термохронам - появилась возможность удалённой записи данных (температуры и влажности) горных почв.

В связи с развитием систем вычисления стала возможна обработка огромных массивов полученных данных. При помощи вышеупомянутых методов стало возможным измерение значимости и надёжности полученных результатов, оценка достоверности проверяемых гипотез, а также выделение из множества воздействующих факторов наиболее существенных.

\section{Список литературы}

1. Зенкова И.В. Летняя динамика температуры в горных почвах заповедника «Пасвик» // Вестник МГТУ. 2013. Т. 16. № 4. С. 715-725.

2. Зенкова И.В. Динамика температуры подстилок в высотном градиенте горы Юкспорр (Хибинский массив) // Проблемы изучения и сохранения растительного мира Восточной Фенноскандии». Апатиты. 2015а. С. 34-35.

3. Зенкова И.В. К характеристике летней динамики температуры подстилок в горах Хибинского массива (Мурманская область) // Фундаментальные и прикладные вопросы лесного почвоведения. Сыктывкар: Коми НЦ УрО РАН. 2015 б. С. 85-87.

4. Штабровская И.М. Летняя динамика температуры в горных почвах Хибин на примере гор Юкспорр и Суолайв / Выпускная квалификационная работа программы бакалавриата по направлению подготовки 05.03.06 Экология и природопользование. Апатиты. 2016. С.59

5. Штабровская И.М. Сравнительная динамика температуры подстилки в лишайниковой и кустарничковой тундре Хибин // Труды XIV Bcepoc. (с межд. уч.) Ферсмановской науч. сессии ГИ КНЦ РАН. Апатиты. 2017. C. 461-464.

6. Штабровская И.М. Исследование температуры горных почв хибин с использованием автоматических термодатчиков // Межд. науч.-практич. конф. Использование современных информационных технологий в ботанических исследованиях. Апатиты. 2017. С. 134-136.

7. Расписание погоды [сайт] URL: http://rp5.ru 